\title{
THE SPECTACLE OF PIETY ON THE BRITTANY COAST
}

\author{
MAURA COUGHLIN \\ Visual Studies, Bryant University, Smithfield, RI, USA
}

\begin{abstract}
Writing in the early 20th century, sociologist Max Weber found the modern world increasingly "disenchanted": belief in the magical and sacred had receded to its uncolonized margins. In France, these margins on the Brittany coast drew a seasonal crowd of cultural tourists throughout the 19th century. Artists and writers who journeyed to the coast of Western Brittany were fascinated by the spectacle of local festive displays such as the yearly religious pardons at St. Anne de Palud. But instead of understanding ritual festivities on the Brittany coast as simply the encounter of an outsider and his or her rural other, we can read these events as collective experiences that provided many ways to be both spectacle and spectator. This article departs from previous studies of art in Brittany in two significant ways: it considers the experience of local travel to coastal festivities (such as pardons) rather than taking tourism only to mean travel on a wider national or international scale. It also widens the focus of previous critical considerations of pardons in paintings to an expanded archive of visual and material culture from the late 19th and early 20th centuries. Rather than equating rural life and representations of it with an outsider's longings for an imaginary past, I employ methodologies drawn from feminist cultural criticism and the anthropology of material culture to view Breton pardons and their forms of visual culture as vibrant and ever changing performances and mediations of place and cultural identity. I consider these yearly public rituals as occasions that are marked as separate from ordinary daily routine yet that are also retrospectively integrated to everyday experience through their material and visual culture. Although paintings are central to my argument, this article takes a short detour away from concerns with artistic representation in order to engage with the bodily experience of the pardon, and then makes a return to the visual. This shift attempts to move past a primary focus on the "tourist gaze" and toward an interest in the experiential, concrete poetics of the festive and its relationship to the "everyday."
\end{abstract}

Key words: Brittany coast; Breton festivals; Breton pardon; Artistic representation; Visual culture

\section{Introduction}

According to sociologist Max Weber (1947), the modern world became increasingly "disenchanted" as belief in the magical and sacred receded to its margins. Over the course of the nineteenth century, coastal Brittany in north-west France came to be known for its pardons: large- scale, outdoor religious events whose festive social practices blur the lines of sacred and profane. Pardons had enormous appeal to visiting writers, artists, photographers, and other "cultural tourists" searching, on the margins of the continent, for just the sort of "enchantment" that Weber (1947) describes.

Late 19th to mid-20th century paintings and 
popular imagery depicting these open-air communal events (Figs. 1-4) have long been ascribed to a form of artistic tourism (Orton \& Pollock, 1980). When Breton visual culture is viewed only through the lens of modern viewers' nostalgic desires for "primitive" or premodern experience, a limited degree of interaction is assumed between a putative modern urban viewer and his or her subject, assumed to be both rural and traditional. However, artists' renderings of Breton festivals were never transparent, objective or without omission, but neither was any other form of representation such as memoir, travel writing, photography, or indeed memory.

I would like to propose that instead of understanding ritual festivities on the Brittany coast as simply the encounter of an outsider and his or her rural other, we can read these events as collective experiences that provided many ways to be both spectacle and spectator. This article departs from previous studies of art in Brittany in two significant ways: it considers the experience of local

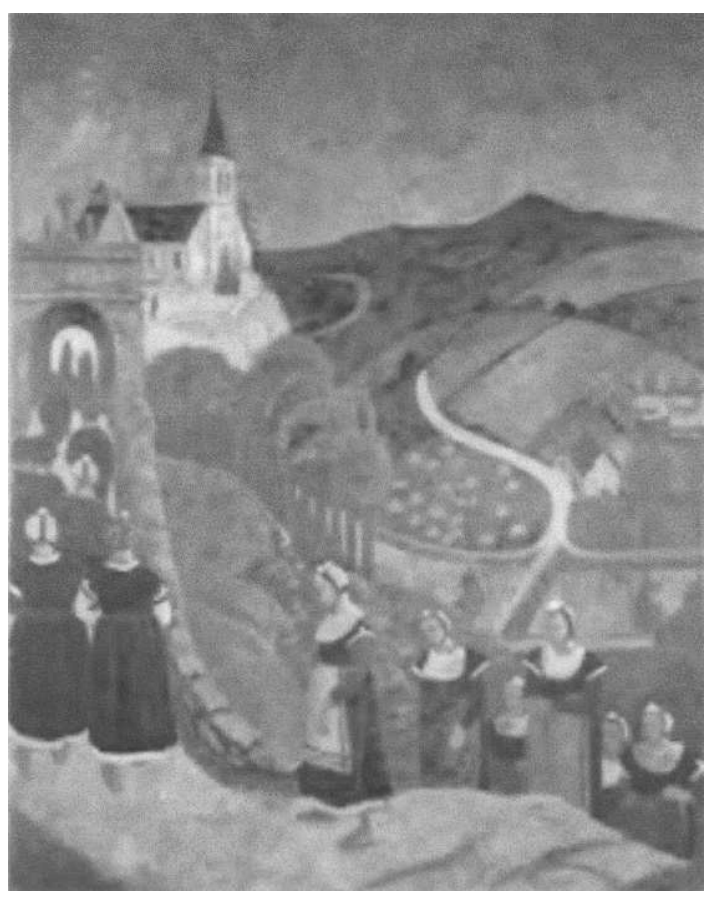

Figure 1. Paul Sérusier. Pardon of Nôtre-Dame des Portes at Chateauneuf du Faou, 1893. Quimper Fine Arts Museum. travel to coastal festivities (such as pardons) rather than taking tourism only to mean travel on a wider national or international scale. It also widens the focus of previous critical considerations of pardons in paintings to an expanded archive of visual and material culture from the late 19th and early 20th centuries. Rather than equating rural life and representations of it with an outsider's longings for an imaginary past, I employ methodologies drawn from feminist cultural criticism and the anthropology of material culture to view Breton pardons and their forms of visual culture as vibrant and ever changing performances and mediations of place and cultural identity (Dant, 1999; Domosh, 2001; Massey, 1994; McDowell, 1999). I consider these yearly public rituals as occasions that are marked as separate from ordinary daily routine yet that are also retrospectively integrated to everyday experience through their material and visual culture. Although paintings are central to my argument, this article takes a short detour away from concerns with artistic representation in order to engage with the bodily experience of the pardon, and then makes a return to the visual. This shift attempts to move past a primary focus on the "tourist gaze" (Urry, 1990) and toward an interest in the experiential, concrete poetics of the festive and its relationship to the "everyday" (Johnstone, 2008).

Most every sort of pardon-old, new, large, and local-made it into travel narratives and visual representation. Held on a saint's feast day at his or her specific church, chapel, miraculous fountain, or holy well, the saint's presence is invoked, in part, by the parading of relics or sacred images (Young, 2007). Crucial to the performance of the pardon is travel to the site: often an act of penance and endurance in itself. In 19th century Brittany, participants often came by foot or over water (Fig. 3): quite literally, the pardon began the moment one left home. Thus, through travel, a very dispersed Breton population was temporarily united in one place in the profession of faith to a saint or holy place (Lacombe, 2001). As Picard and Robinson (2006) write of 20th century destination festivals, one can view the Breton pardon as a social relationship mediated by images. A wide range of visual and material culture relates to the pardon, from relics (with their obvious auras 


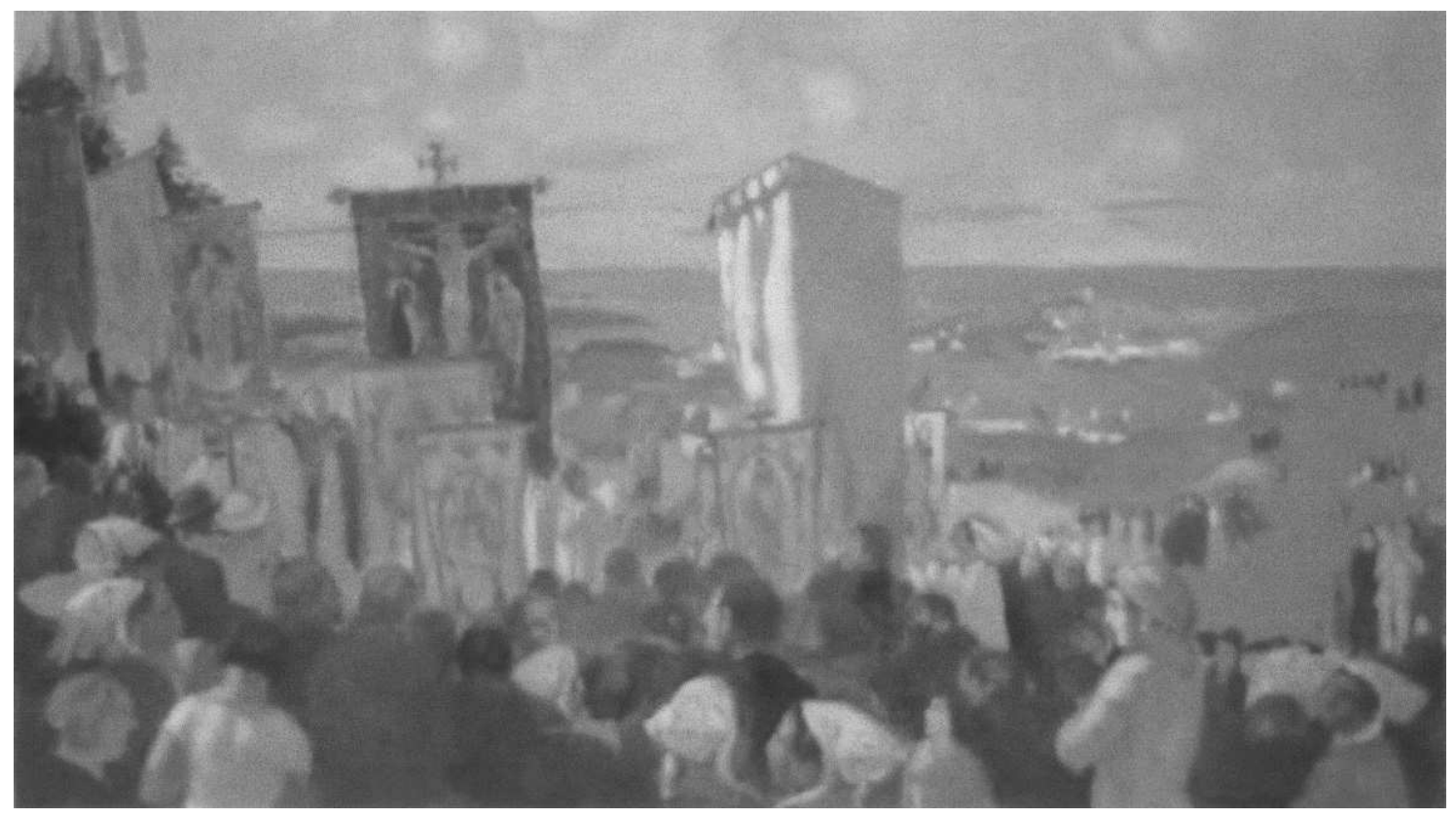

Figure 2. Maurice Denis. Pardon of Nôtre-Dame de la Clarté, 1926. Kerazan Manorhouse, Loctudy, France.

of presence) (Dant, 1999) to large-scale and ambitious paintings (produced by a wide range of artists) to mechanically reproduced popular devotional prints or postcards (Cariou \& Le Stum, 1997).

Throughout the later 19th and early 20th centuries, as Breton pilgrims flocked to pardons, the spectacles were simultaneously consumed by Brittany's burgeoning tourist industry (Puget, 2006; Young, 2007). At the forefront of this were bohemian artists, typified by the colony at Pont Aven (best known for Paul Gauguin and his circle). Encouraged by the novels and folkloric compilations of popular writers such as Le Braz and Pierre Loti, artists and many other spectators of pardons willed themselves to believe that they were witnessing true survivals of ancient, even pre-Christian, religious culture. In an influential article published in 1980, art historians Griselda Pollock and Fred Orton (1980) debunk much of this myth, explaining that costumes worn to pardons in the later 19th century were not timeless or archaic although artists may have fancied them so: these elaborate festive outfits were relatively recent inventions that coincided with the availability of industrially man- ufactured cloth. Rather than being universally "Breton" they signified very specifically on the local level as to the village, family, wealth, and marital status of the wearer.

Although Pollock and Orton's (1980) article very aptly emphasizes the sociocultural construction of "Brittany" by artists working in the area, it also effectively shuts down further discussion of the visual culture of the pardon. This is to say that after the publication of this article, it was only too easy to read artists' representations of Breton festive culture as mere evidence of their touristic, nostalgic, and somewhat misguided longings for an already lost or imaginary authentic Breton past (Chapman, 1995). Without losing sight of the constructed nature of images, objects, and narratives, I wish to explore some representational dimensions of the pardon that escape this deconstructive approach.

The western tip of Brittany, the départment of Finistère, was named for its location (finis terra) at the end of the earth. In French literature and visual culture, this region signifies the furthest frontier of an agricultural country that has no internal wilderness. Coastline is a dramatic sort of 


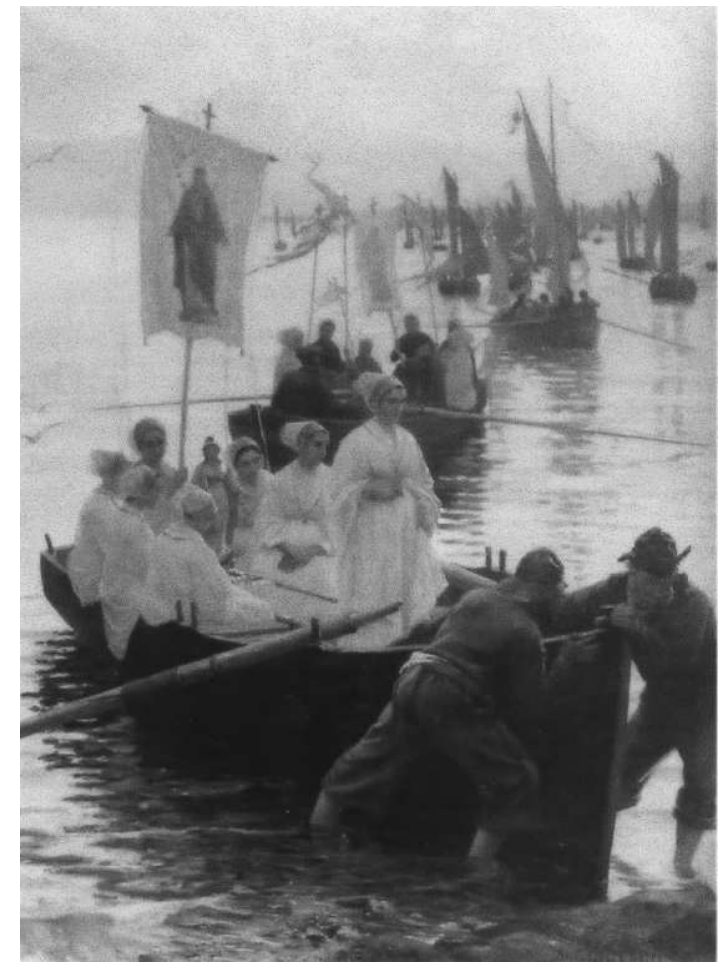

Figure 3. Alfred Guillou. Arrival of the Pardon of SainteAnne-de-Fouesnant in Concarneau, 1887. Quimper Museum of Fine Arts.

landscape, either desired or feared. Because it articulates a natural border, crossing it entails a shift of one's mode of travel. Yet it is not a static threshold of the land: it moves with tides, storms, erosion, and accretion. It is a common device of French 19th century poetry and painting that men look to sea from the shore; pondering the infinite forces of nature that authors like Jules Michelet (1861) celebrated in La Mer. Contemplating nature was, of course, a way of thinking about the emotive, melancholic modern (male) self: the artist, the writer, the one whose temperament filters visions of the natural world (Corbin, 1994). In mid-19th century depictions of artists on the strand, we are encouraged to experience an encounter between the male subject and the vast, liquid expanses of the sublime (and often feminine, devouring) sea. In the words of French feminist and psychoanalyst Luce Irigaray (1991) this relationship, that is so dependent upon cultural dis- tinctions of gender and nature, posits that "whoever looks upon her from the overhanging bank finds there a call somewhere further than the farthest far. Toward another ever more other. Beyond any anchorage yet imaginable" (p. 47).

Coastal pardons attracted many kinds of tourists from within (and without) the region: Parisians, international travelers, and Bretons who had left the province for education or employment flocked to the coast in summertime. Travel to the Brittany coast (such as the sandy beaches of the north coast) by visitors from outside the region initially followed the train lines laid down in the nineteenth century. In the first two decades of the 20th century, new roads and automobiles brought in even more travelers (Young, 2007). This was the most obvious manifestation of tourism in the province. Within Brittany, pardons also brought together an infrequently mobile female population that was often isolated on islands or in villages with little outside contact. On the coast of Finistère, most adult men fished or shipped out in the merchant marine for most of the year; women were left behind, tied to the land, the hearth, and the family. In French painting and popular imagery of the 19th century, rural women in Brittany are often positioned by the sea, as features of the landscape, to be looked at as they work, wait, watch, mourn, gossip, and, occasionally, take part in religious gatherings.

Pardons were mostly held in the warmer months-from Easter to All Saints. The larger ones were quite well-organized spectacles: candlelit vigils began the night before as pilgrims arrived to circle or pray at a holy building, well, or stone. Processions held during daylight hours included groups of girls in spectral white communion gowns, widows, grateful shipwreck survivors, sailors carrying votive model ships, strapping young men bearing village banners, others with crosses, ex-votos, reliquaries, and other statuary; there were musicians, members of the clergy, town fathers, and many other pilgrims dressed in local costume. Guidebooks told the unacquainted viewer that certain climactic moments of the pardon were not to be missed, such as the "meeting of the banners," a combative situation that arose when a banner bearer refused to step aside and let a bearer from a neighboring village pass with his 


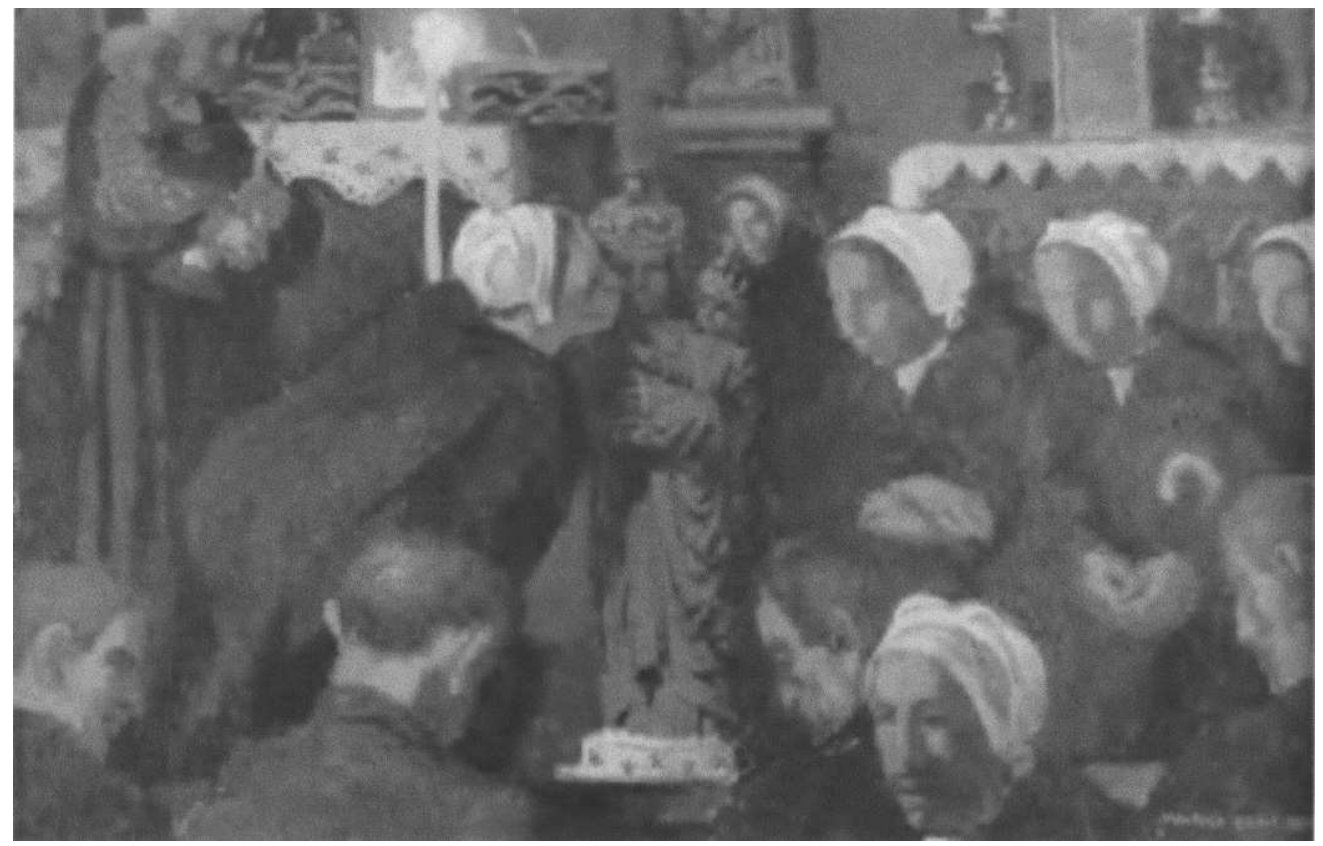

Figure 4. Maurice Denis. The Virgin of Le Folgoët, 1930. Quimper Museum of Fine Arts.

rival banner (Lacombe, 2001). This very local competition of symbols and patron saints articulated the logic of Sigmund Freud's (1929) "narcissism of minor differences"; it was a vehicle for the harmless expression of local difference among neighbors who came together at the pardon.

What has been called the "golden age" of Breton pardons coincides roughly with the religious revival of the French Third Republic, stretching from the mid-19th century to the prewar period. At this time, Catholic practice in France was reinvigorated (after the iconoclasm of the Revolution) picking up steam from repeated visionary appearances of the Virgin. In Brittany, theophanies of Mary, St. Anne, and other saints (as well as the uncanny unearthing of their ancient statues) inspired their local cults and devotional practices (Cariou \& Le Stum, 1997). Such tangible manifestations of the miraculous, along with a growing interest in local saints in Brittany (as in other parts of rural France) catalyzed the popular pilgrimage movement of the 1870s. Although the Church (in the wake of the Counter-Reformation) had previously suppressed popular religion in Brittany, this modern movement received official sanction in hopes that its popular appeal might counterbalance republican secularism (Anson, 1965; Kaufman, 2005; Thomson, 2004).

Historian Suzanne Kaufman (2005), in her analysis of the highly commercialized Lourdes miracles, notes that, in most modern narratives, belief in the magical and sacred recedes to the margins, as Weber (1947) suggests, and then "reemerges, following the logic of Karl Marx's analysis of modern capitalism, as a profane magic of the marketplace in the form of commodity fetishism" (Kaufman, 2005, p. 6). This notion of progressive cultural secularism, wed to a suspicion of the inherent falseness of our interactions with material objects has its limitations: a persistent academic perspective (that depends heavily upon Michel Foucault's theories of discursive formations) views representations of provincial culture as a set of commodities that have been culturally encoded and packaged for urban consumers (Green, 1990). There is a somewhat cynical incompleteness to such arguments that leaves no room for multiple and shifting experiences articulated-in partthrough bodily experience (Dant, 1999).

Visual and material culture produced for, by 
and in response to festive piety in Brittany played an active role in mediating, marketing, and memorializing the local culture. The very participants that artists, writers, and photographers represented were themselves consumers of popular rituals and material culture that was ever vibrant and changing, even in the face of national secular policy. Although the call for a legal separation of church and state gained momentum over the course of the Third Republic, and was officially declared in 1905 , religious culture in Brittany continued to reinvent itself, with new pardons instituted in the early 20th century. Yet many visual representations of pardons in the late 19th century echo Weber's (1947) nostalgia for the receding enchantment of a vanishing, "primitive" culture. This is to say that these rituals are framed as vestigial survivals of faith in pre-Christian sites, pagan fertility cults, and Celtic saints that were transparently Romanized. Just as prehistoric standing stones or menhirs were recarved or topped with a cross, Breton Celtic ritual, we are repeatedly told, was Christianized, with the fetishistic behavior of the old faith merely transferred to the new.

Folklorist Anatole Le Braz (1894), in his wildly successful ethnographies and novels of the turn of the last century, and especially in his popular guide $A u$ Pays des Pardons, characterizes Brittany as a land of superstition and death. For him, Breton pardons had an archaic and primitive appeal, rooted in a deep and dark Celtic past. His texts encouraged many tourists who traveled to Brittany from outside the region to understand religious spectacles as authentic and timeless Breton tradition surviving tenaciously, yet threatened by modernity, on the edges of the modern French nation (Besançon, 1996; Young, 2007).

Instead of preserving ancient ways, pardons spoke to the ongoing flexibility, continual reinvention, and local meanings of faith in this area (Besançon, 1996). Just as a religious building that has been continuously in use, which has been repainted, enlarged, damaged, repaired, restored, and reinterpreted develops a layered or eclectic nature, the pardons had an appealing vitality for spectators and participants alike precisely because they had not been fixed or museumized into one prescribed "authentic" form. Like the popular prints sold as souvenirs whose stylized "primitivism" was reproduced using modern printing presses, the pardon's old time appeal could absorb and reframe modern realities - at the same time that it united a dispersed Breton population: whether traveling to it on foot, over water, by bicycle, train, or car.

On the north coast of Finistère, the village of St.-Jean-du-Doigt has long claimed to own a relic of St. John the Baptist's finger. The pardon held there in late June coincides with the summer solstice, or Midsummer's Eve, and culminates in a great bonfire. Midsummer Eve bonfires in Brittany, according to Scottish social anthropologist, Sir James Frazer (1890), are the residual remains of primitive magical practice. St. John's Breton cult most likely arose from the Romanization of a Breton St. Meriadek, a former Bishop of Vannes who may have, in turn, replaced a Breton sun cult of Hëol (Helios). Echoing Frazer, Le Braz (1894) notes on Finistère that "perhaps in no other region of Brittany has the ancient Celtic nature-worship remained so unaltered" (p. 133). When describing St. John's pardon, Le Braz defers to previous descriptions (Cambry, 1799) in which the fire was ignited after the late sunset by an "archangel, glittering with flames and fireworks, [who] pierced the shadows, flew straight to the pile, lit it, and after having fanned it with his wide-spread wings, vanished into the darkness" (Le Braz, 1894, p. 143).

There were efforts by the Breton Catholic Church to put a stop to these fabulous pyrotechnics in the mid 19th-century and, in several locations, religious authorities insisted that the fire (in Breton, tantad or "first fire") burn in daytime. Le Braz (1894) finds this modern practice disappointing as he imagines the earlier, pagan, more fearinspiring display:

What frantic dances there were around the Tantad! And, afterward what mad home-goings under the warm June sky, glittering with stars! Many people never went home at all, but ran about the shore or the country all night pursuing each other with wild cries ... and flaming brands ... I fancy that it must have been to put an end to these very disorderly disturbances, in which the very women themselves took pleasure that the authorities decided to hold the Tantad in daylight, immediately after Vespers. (p. 143)

By the time that Le Braz (1894) makes his own pilgrimage to witness "The Pardon of Fire" 
he notes that many in the crowd come for the fire alone-and that the locals demand a small fee of spectators who stand in their fields. Although many photographic postcards from the early 20th century depict these visually underwhelming daytime bonfires (Fig. 5), their modern incarnations are not the stuff of dramatic paintings or popular images.

Referring to St. John's night festivities in his home village in the Artois, Academic Naturalist Jules Breton paints a barefoot dance about one of several midsummer bonfires that stretch across the fields at dusk, playing up the sensuality of barefoot peasant women backlit by a golden sky, a glowing moon (Fig. 6). This is just the sort of formula used by the illustrator who depicts the St. John's bonfires on the cover of Le Petit Journal in the summer of 1893 (Fig. 7). In this version of the midsummer bonfire, costumed Bretons dance around fires that emit great billowing clouds of smoke. Their circular dance is echoed at the base of the stone Calvary behind them where sculpted worshippers, surrounding the crosses, mark out the place as a site of ritual pilgrimage.

Painter Charles Cottet (who at the time lived year round in the fishing town of Camaret) depicts late night midsummer fires on Ouessant that spread out along the shore of the island and illuminate the horizon like a false dawn (Fig. 8). In the moody darkness that was typical of this artist's work, a group of elder widows, cloaked in black, sit by a ring of stones that contains a small fire of driftwood and seaweed. Le Braz (1894) tells us that, on this shortest day, when the living and the dead are in close proximity, superstition dictates that a litany for the dead be said to the souls who come to join the living. He notes that because Breton hell is cold, rather than hot, wandering souls are forever trying to get warm, and thus they gather by the bonfire's embers. The rocky coast of western Brittany has often been represented as a space of departure, longing and death, and the

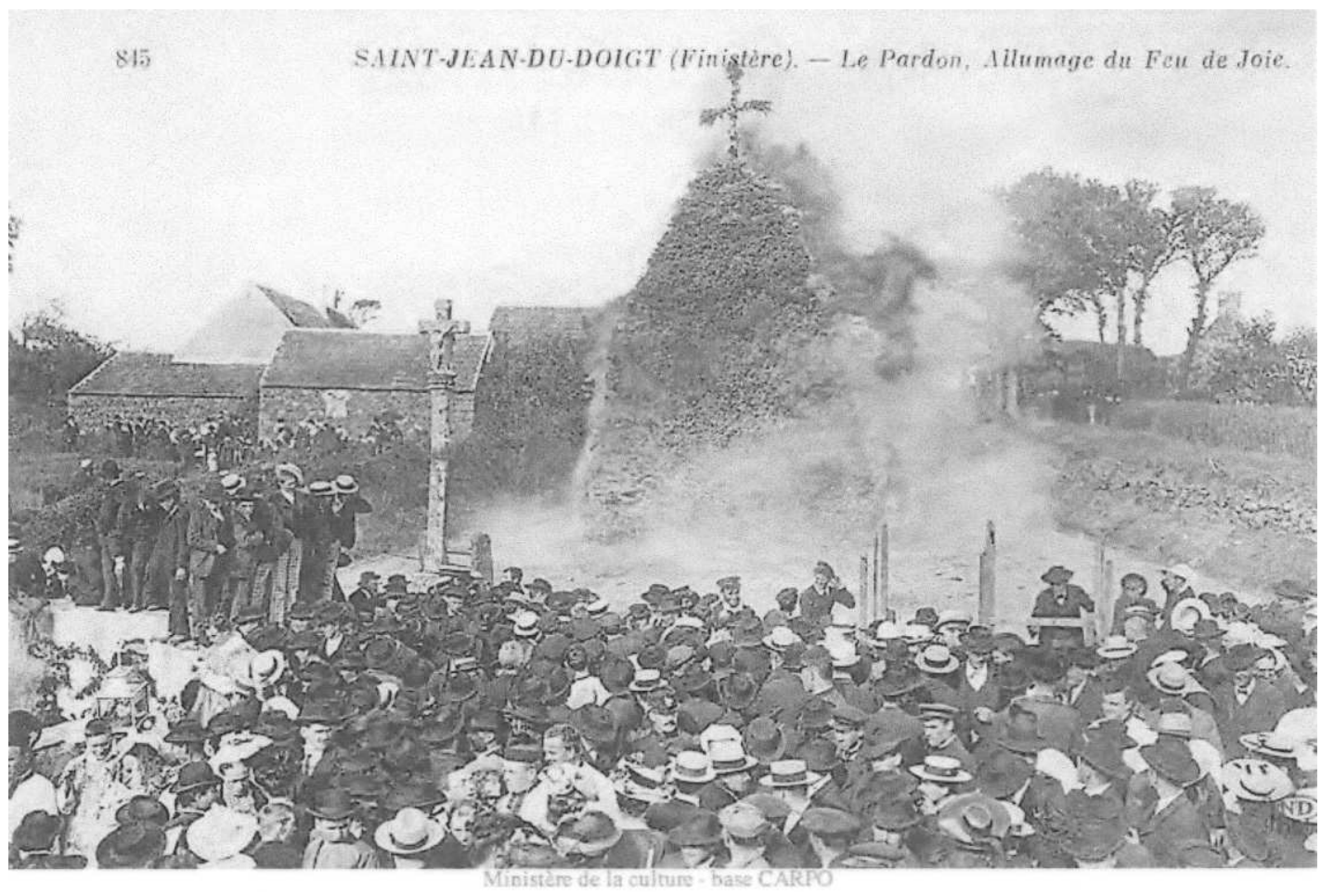

Figure 5. Postcard image of Saint-Jean-du-Doigt bonfire. Early 20th century. Museum of European and Mediterranean Civilisations, Marseilles. 


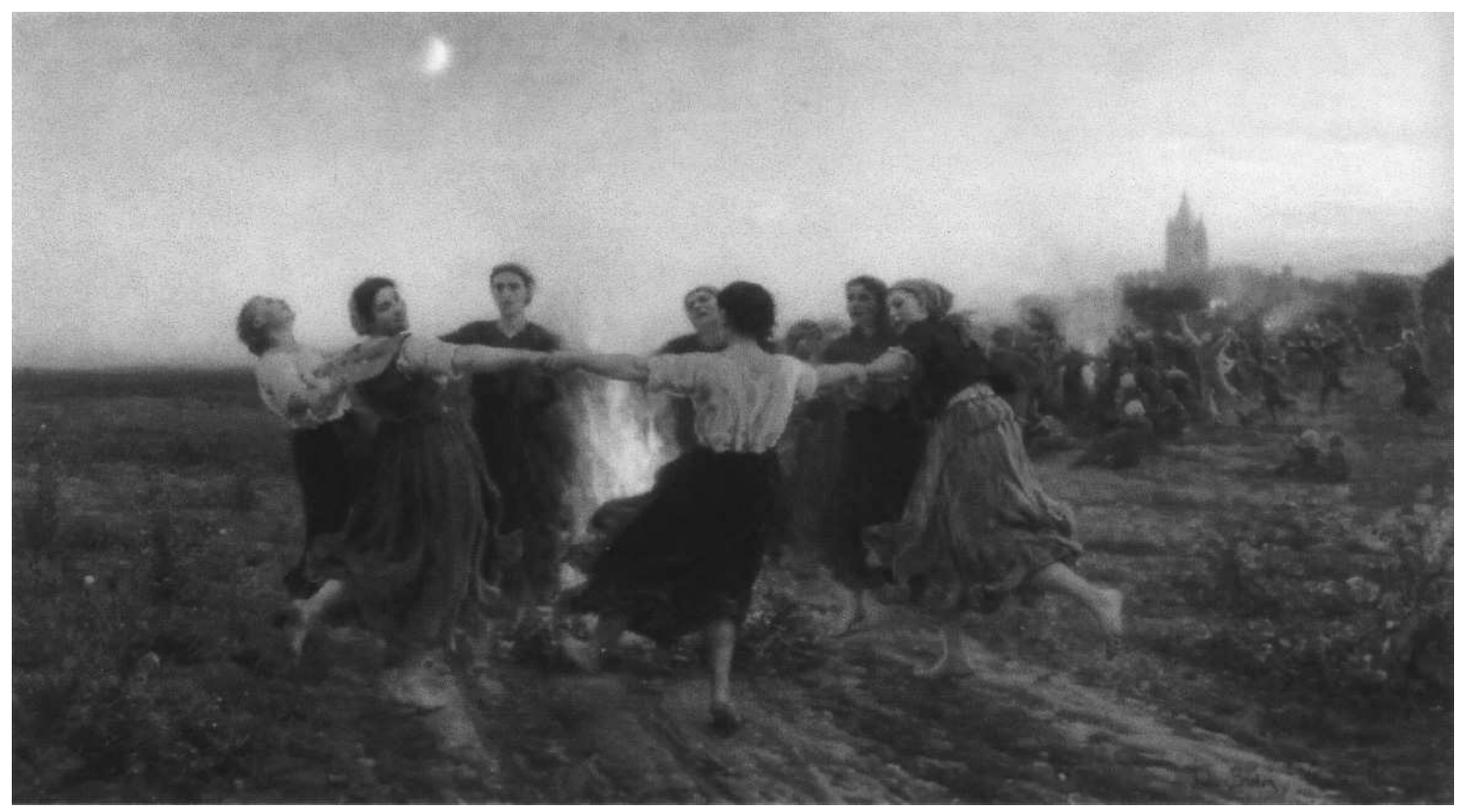

Figure 6. Jules Breton. Festival of Saint John, 1875. Private collection.

Breton islands of Batz, Sein, Ouessant, Molène, and Belle-Isle have been described, since the late eighteenth century (Cambry, 1799), as remote, wild sites of mysterious ritual. These islands have been imagined as places where one might return to the origins of humanity and find pure repositories of human culture, languages, and even animal species that have died out elsewhere (Salomé, 2003). One is entirely surrounded by coastline on these small islands: the sea is in every, but no one direction on the compass, and, as Historian Françoise Péron (2004) notes, its "omnipresence... intensifies the feeling of being cut off from the rest of the world" (p. 330). In a series of paintings and etchings, Cottet repeats the image of the St. John's night bonfires on Ouessant surrounded by female faces: like Le Braz (1894), he is interested in this threshold moment of ritual, a seemingly pious Christian practice steeped in Celtic folklore. Rather than the large crowds of tourists described by Le Braz at St. Jean-du- Doigt, or the festive dancing Bretons of the Petit Journal image, Cottet's is an image of islanders and extended family, of small-scale local practices where death, memory, and remembrance come together. Painters Cottet, Paul Sérusier, and Maurice Denis re-

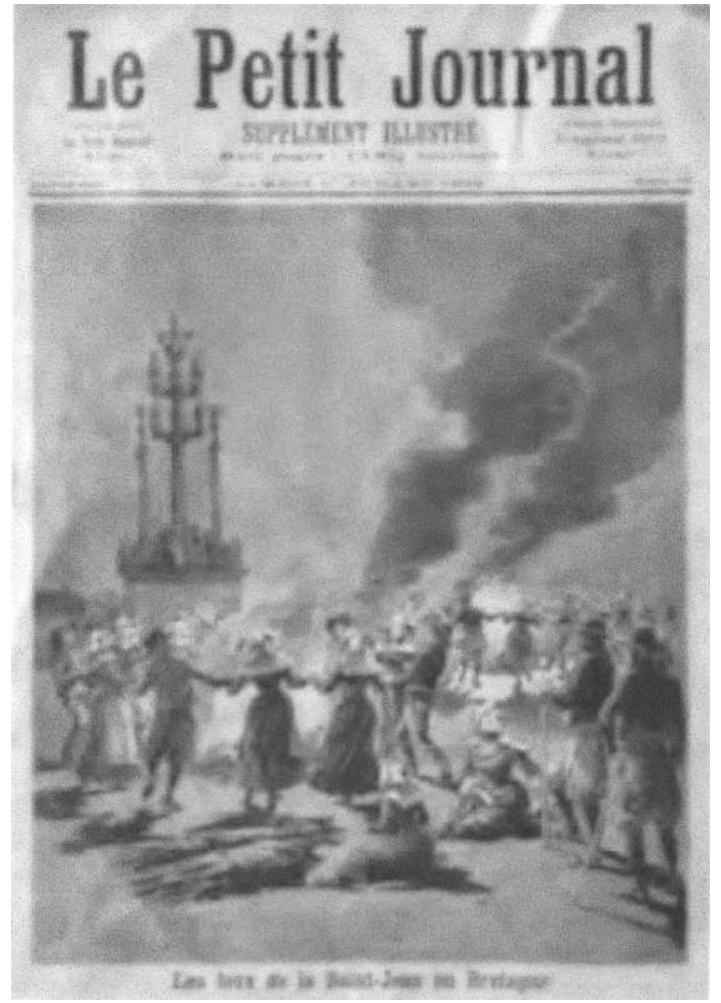

Figure 7. Le Petit Journal, 1893. In author's collection. 


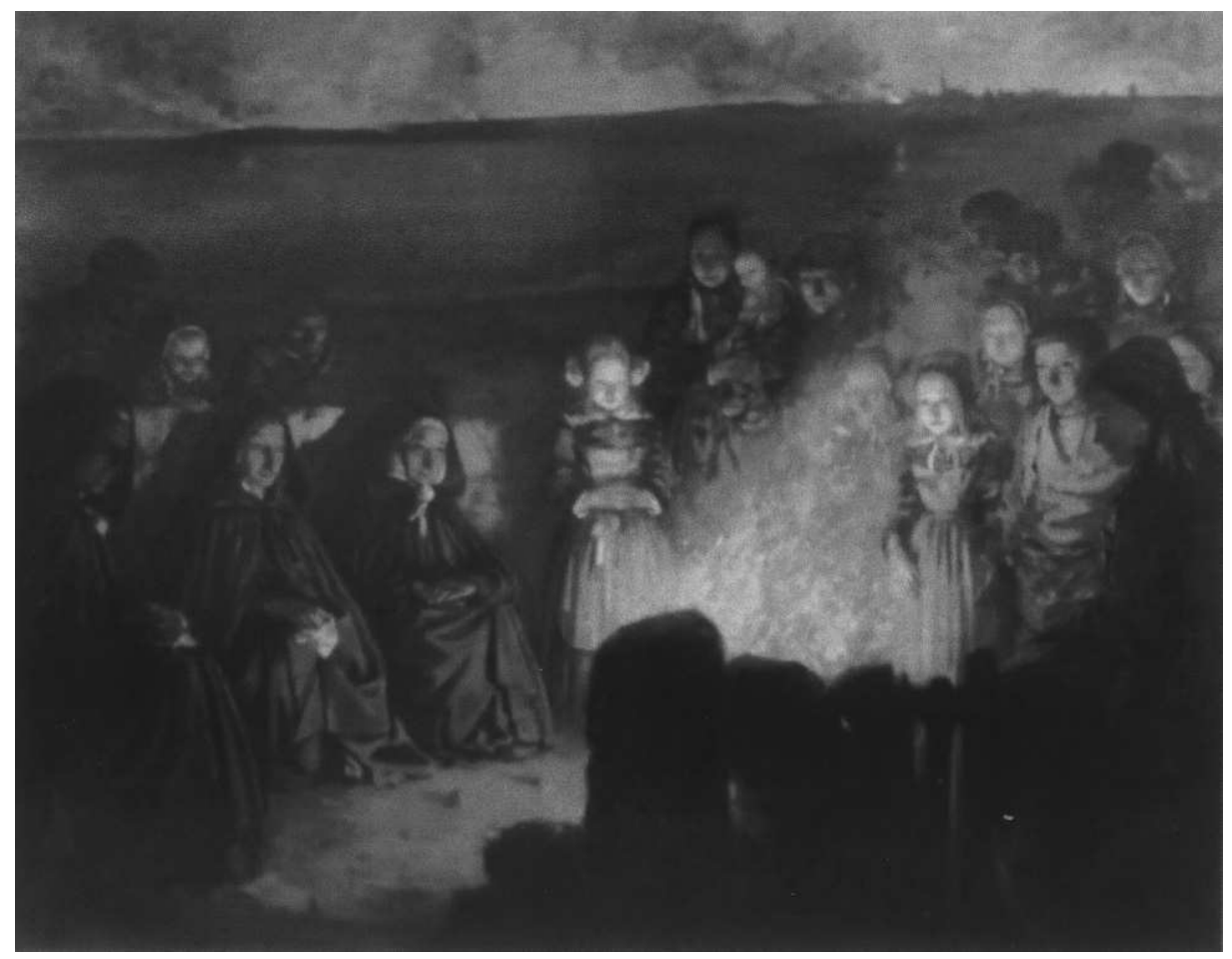

Figure 8. Charles Cottet. St. John's Bonfire on Ouessant. Private collection, Brest.

turn to the midsummer bonfire for decades, representing Finistère's darkly festive culture of female piety.

On offshore islands such as Ouessant, because its male "residents" were forever at sea, women bore the burdens of agriculture, maintaining the home, child rearing, and just about every other aspect of the everyday. For these women, pardons provided a rare opportunity to stop working and to travel: this was a limited local tourism within Brittany more akin to a pilgrim's journey than a restful modern vacation. Thus I wonder, what it could have been like, for a rural girl, to be one of the large crowds in the pardon-to take a break from the dirt, smells, and hard work of daily life, what was it like to be looked at as part of the image that was the pardon? To grow up in a small village meant that there were no strangers and no secrets either: being spectacular, being unknown, being even a small bit exotic-this was undoubtedly exciting.

A participant's sensual, bodily experience of a pardon in Brittany is outlined by Breton-born author Jacques Cambry (1799), in his travel account of the postrevolutionary state of Finistère in 1795. He describes a pardon quite specifically as an interaction with a specific place such as:

a chapel, a fountain, a place devoted to the memory of some saint, of some miracle. There you confess, take communion, give alms, submit to superstitious practice; there you buy crosses, rosaries, and images to touch to the statue of the demi-god; there you rub your face, your forehead, your paralytic arm on a miracle-working stone; there you throw coins and pins into the fountains; you soak a shirt in one in order to be cured, or a belt to assure child-bearing without pain. You leave after having danced, having gotten drunk, money all spent but full of hope. (pp. 54-57)

After the daytime penitential acts of circling the site, walking in procession, and attending high mass, pardons often descended into festive celebration (Cariou \& Le Stum, 1997). In addition to 
bonfires, this carnivalesque atmosphere might include games, wrestling, folk music, and dances. Beggars gathered, vendors hawked food, religious souvenirs, and popular prints, teeth were pulled by traveling dentists, and naive country girls were conned out of their tresses by traveling wig makers. The church was anxious to suppress the almost inevitable evening drunkenness, brawling, flirting, dancing, crass commerce, and even public nudity that followed the day's more solemn events (Lacombe, 2001). The pardon participant as well as that of the tourist visiting from outside of Brittany may have engaged with a plurality of bodily experiences (Crouch, 2003).

In a culture where Sunday mass offered the only relief from the week's labor, the clothes worn to pardons were as different as they could be from the seldom-washed, hemp work clothes that we see so often in early 20th century images of Breton coastal women at work: digging clams, harvesting and burning sea weed, cleaning fish, etc. Historian Patrick Young (2009) examines the emergence of heritage tourism and its fixation upon festive costume in the early 20th century. In his reading of travel narratives, he cites a guidebook for English travelers published in 1929, in which the reader is encouraged to imagine the perspective of the peasant participant, who may "seize the occasion to lay aside her poor workaday clothes and put on her treasures, kept in the family chest under the closed-in bed." As sociologist Tim Dant (1999) notes "clothes have meanings which are not properties of the garments but of the garments-in-a-situation" (p. 97).

Dressing for a pardon indeed provided a rare occasion for an aesthetic attention to detail in starching and arranging a coiffe, in ironing and dressing in heirloom clothing. Cottet depicts a large-scale pardon as a respite from the everyday in his highly decorative, colorful canvas, Women of Plougastel at the Pardon of St Anne de Palud (1903) (Fig. 9). In Cottet's painting, as in many photographs of pardon crowds from the early 20th century, women of particular villages or parishes stay grouped together even when at leisure (undoubtedly this gathering was also a rare opportunity to meet a man from another village). In this painter's extensive (and often coloristically dark)

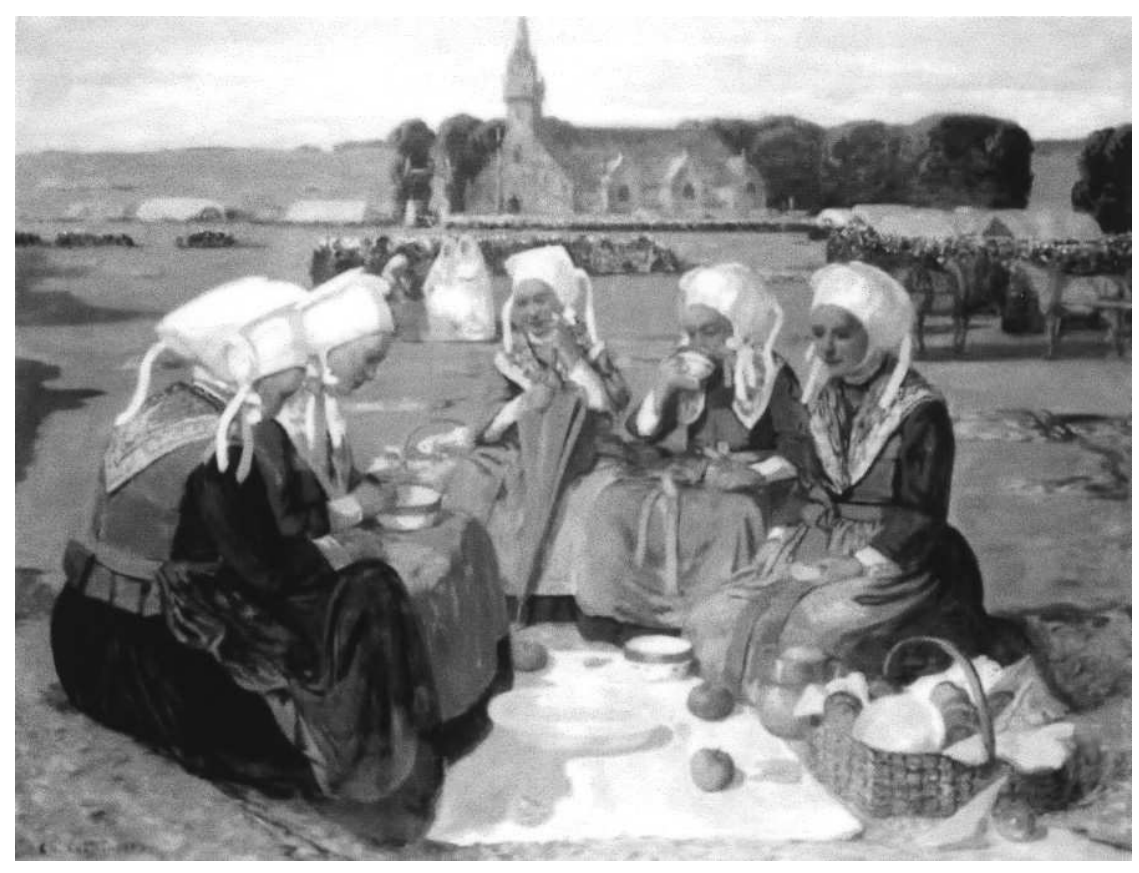

Figure 9. Charles Cottet. Women of Plougastel at the Pardon of St. Anne de Palud, 1903. Rennes Museum of Art. Licenses through Art Resource, NY. 


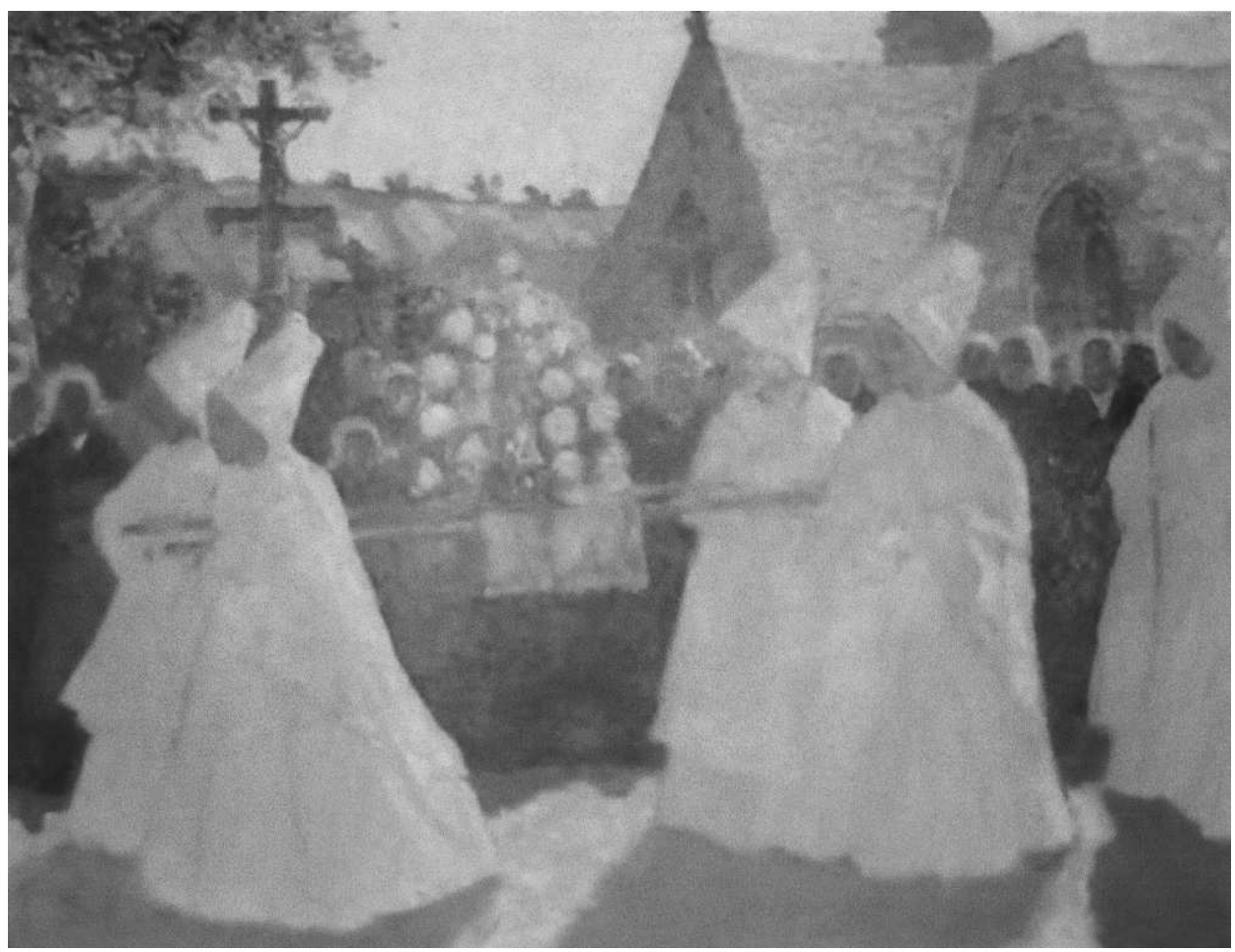

Figure 10. Charles Cottet. Festival at Landudec, 1902. Kerazan Manorhouse, Loctudy, France.

work in Brittany, pardons are one of the few places where dazzling color calls attention to the exceptional nature of the events depicted (Fig. 10) (Cariou, 1988). Separated from the dirt, fish, and salt of daily life, five women are depicted taking pleasure in a peasant holiday of the body; the everyday grind has been transformed by ritual and this is expressed through costume. The same brightly colored costumes (that effectively declared and enabled them to perform their local identities at this pardon) roused the ire of a conservative cultural critic, generally supportive of Cottet's career: none other than the author of "Degeneration," Max Nordau (1907). Complaining of the "shrill penny-trumpet tones" (p. 214) in this painting, Nordau (1907) deplores the vulgar choice of Cottet to sink to the popular taste of rural women, no matter how true.

Nostalgic treatments of Breton culture may favor sepia-tinted lenses, but popular taste was often wildly colorful in the everyday life of the Breton home. Presented as typical of a peasant interior c. 1900 in the Niou Ecomuseum on the island of Ouessant, the hearth is surrounded by pardon souvenirs such as statuettes, rosaries, and popular prints (Simon, 1997) (Fig. 11). Devotional prints such as these were cheaply printed by the thousands in large publishing houses in Rennes and Quimperlé and were sold at pardons and by traveling merchants. A standard format of these prints is to surround iconic images of a saint with smaller narrative images of miracles, devotional texts, and blessings. Locally significant saints whose images proliferate include Saint Anne (patron saint of sailors) who was the focus of two major Breton pardons in Auray and Palud. Breton legend tells that the Virgin's mother was born a Breton queen in the port town of Douarnenez before she went to the Holy Land (Anson, 1965; Cariou \& Le Stum, 1997). At home, these prints blessed the hearth and protected the family, all by way of making reference to the event of the pardon and the contact with its place experienced by the one who had traveled. For a population with a very low rate of 


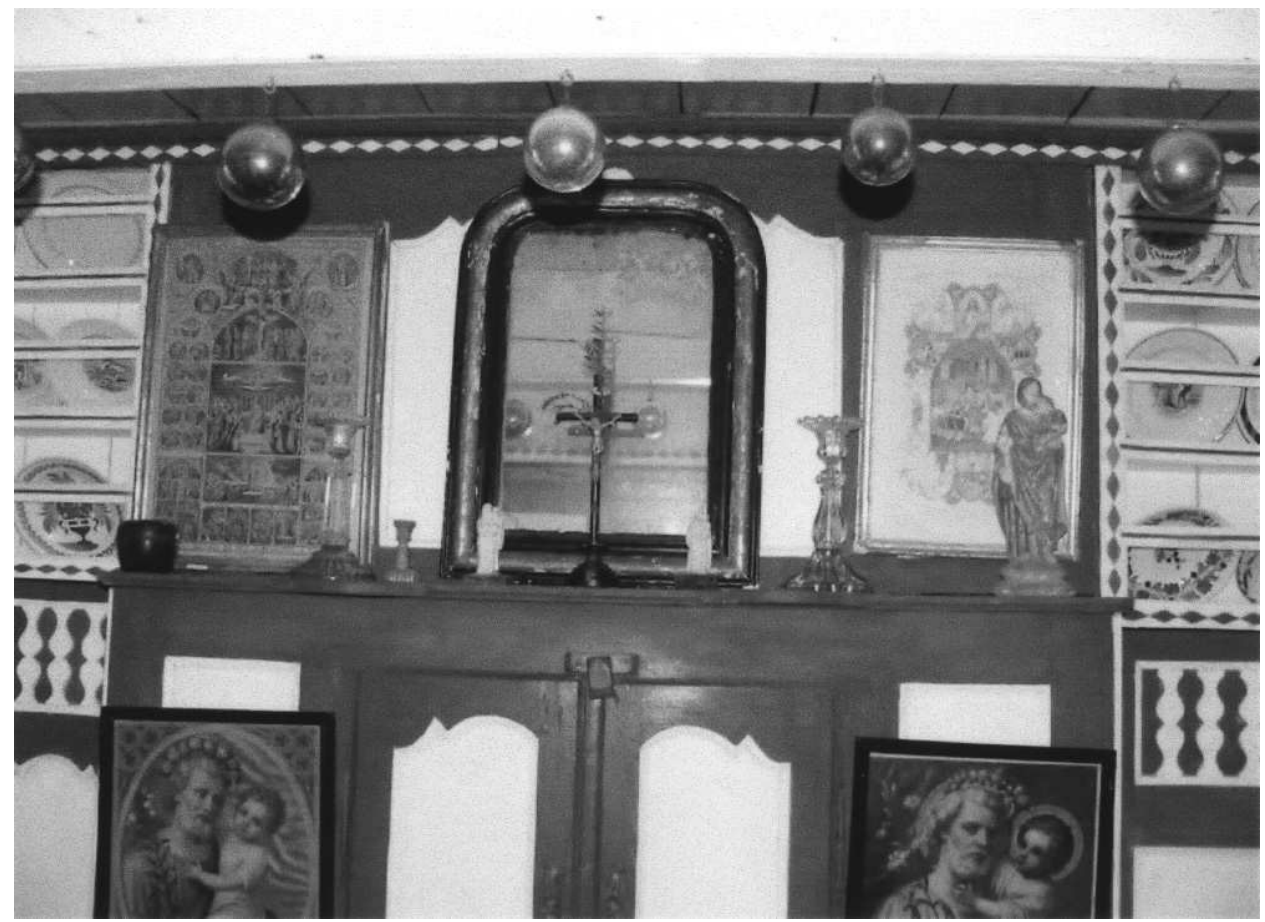

Figure 11. Popular prints surround the mantle in the Ecomuseum of Niou, Ouessant.

literacy (Ford, 1990) images like this were important mnemonic markers that could return the viewer to the significant event of the pardon and that could serve as a continual reminder of his or her spatial and performative experience of the festive event. Like pardon costume, these material objects gained meaning by the ways in which they were displayed and consumed (Dant, 1999). The pardon souvenir might interact with everyday life and thus bridge spatial and temporal distances for the former participant (and other viewers).

A popular print, Notre Dame de Grace (Fig. 12), sold at maritime pardons, was produced by a major publishing house in Normandy. Mary stands upon a flying galleon: the famous ship of Don Juan of Austria, Christian vanquisher of the Turkish fleet in 1571. Allegories of Europe and a still savage America are united under a banner declaring the glory of Mary and Jesus. Below this is a second boat, a crucified Christ on its mast, making another spiritual voyage. Mary here is presented as patron saint of both sailors and travelers. The journey at sea is conflated with the journey of life; the travels of a sailor encompass the local and global, the historical and colonial. A fusion of tradition and modernity, narrative and allegory, these souvenir prints, when viewed in the space of the home, could have generated a range of narratives for their everyday viewers. And these narratives were undoubtedly shaped by gender, for families in coastal villages were seasonally divided: ablebodied men and boys shipped out for months - if not years - at a time. Women's lives were as intensely rooted to the local as the men's were nomadic, fluid, and global.

In the coastal towns of Finistère stand many chapels devoted to Mary, Virgin of the sea, and protector of fishermen. Sailors often made pilgrimages to these sites for pardons before long voyages, or marched in penance and thanks after return (Anson, 1965). Her chapels, some of which are built with roofs like inverted ships' hulls, have walls covered with plaques giving thanks for the return of sailors, mourning the lost at sea, and memorializing shipwrecks. In some chapels, votive model boats hang from the rafters, echoing the 
small boats made of bread that were replaced each year in the cottages of fishing families (Fig. 13) (Cariou \& Le Stum, 1997). In "Pardons of the Sea" widows (veuves de la mer) preceded the saved (les sauvés) in processions. In Paimpol, a winter pardon dedicated to the of cod fishermen departing for the Iceland sea began in 1855 but, due in part to the popularity of Pierre Loti's melodramatic novel, A Fisherman of Iceland (1886), it became a secular festival in 1904. This national policy met great resistance in Brittany, whose staunch Catholicism was born witness to in a newly invented pardon to Our Lady of the Shipwrecked, that in 1904 (just 1 year prior to the legal separation of church and state) drew massive crowds from all corners of Western Brittany to the Pointe du Raz in Plogoff. As the cod fisheries died out, so did many pardons for those departing for the Icelandic and Newfoundland banks-however,

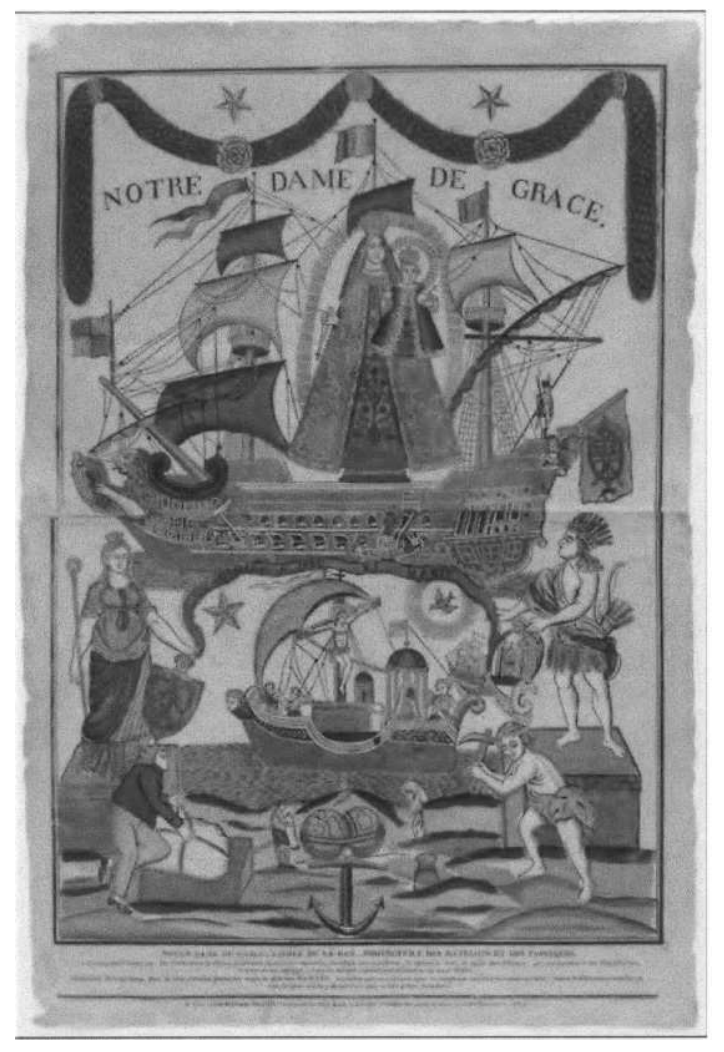

Figure 12. Nôtre Dame de Grace, printed in Caen (Normandy), 1830. MuCEM.

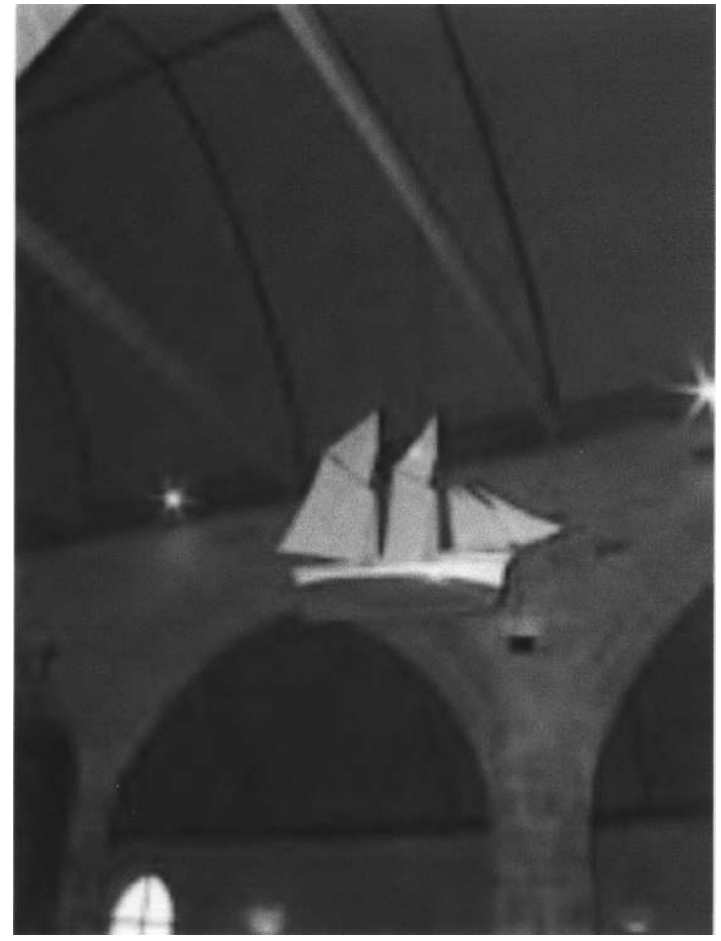

Figure 13. Votive model boat. Nôtre Dame de Rocamadour, Camaret.

the latter was reborn in a new location as a heritage festival in St. Malo in 1926 (Lacombe, 2001; Young, 2007).

From paintings to historical costume to pardon souvenirs, the visual remains and representations of Breton pardons are understood today within the context of heritage tourism in Brittany. Removed from functionality and placed on mannequins in glass vitrines, local variations of pardon costumes now bear witness to particular historical moments. Paintings of pardons by lesser-known artists are often used, alongside enlarged postcard images, to attest to the veracity of historical reconstructions. Each large town on the coast has a museum of rural life, art and history museum, or ecomuseum in which the community may represent itself to visitors and residents alike. Particular pardons are reenacted by locals for summer tourists, as they bring welcome income to coastal communities. Through the museumification of images and objects and the reframing of the event itself as a heritage festival, Breton pardons have come to be un- 
derstood as primarily visual experiences that bear only the traces of collective, participatory, and material interactions.

\section{References}

Anson, P. (1965). Fisher folk-lore: Old customs, taboos, and superstitions among fisher folk, especially in Brittany, Normandy, and on the East Coast of Scotland. London: Faith Press.

Besançon, D. (1996). Anatole Le Braz et la legende de la mort: Traditions populaires et création littéraire. Rennes: Terre de Brume.

Cambry, J. (1799). Voyage dans le Finistère ou État de ce Département en 1794 et 1795. Paris: Cercle-social.

Cariou, A. (1988). Charles Cottet et la Bretagne. Douarnenez: Le Chasse Marée.

Cariou, A., \& Le Stum, P. (1997). Pardons et pèlerinages de Bretagne. Rennes: Ouest-France.

Chapman, M. (1995). "Freezing the frame:" Dress and ethnicity in Brittany and Gaelic Scotland. In J. Eicher (Ed.), Dress and ethnicity: Change across space and time (pp. 7-28). Oxford: Berg.

Crouch, D. (2003). The sensuous in the tourist encounter. Tourist Studies, 3(1), 5-22.

Corbin, A. (1994). The lure of the sea: The Discovery of the seaside in the western world, 1750-1840. Berkeley: University of California Press.

Dant, T. (1999). Material culture in the social world. Buckingham and Philadelphia: Open University Press.

Domosh, M. (2001). Putting women in place: Feminist geographers make sense of the world. New York: Guilford Press.

Ford, C. (1990). Religion and the politics of cultural change in provincial France: The resistance of 1902 in lower Brittany. The Journal of Modern History, 62, 1-33.

Frazer, J. (1890). The golden bough: A study in magic and religion. London: Macmillan.

Freud, S. (1929). Civilization and its discontents (reprint 2005). New York: Norton.

Green, N. (1990). The spectacle of nature: Landscape and bourgeois culture in nineteenth-century France. Manchester: Manchester University Press.

Irigaray, L. (1991). Marine lover of Friedrich Nietzsche. New York: Columbia University Press.

Kaufman, S. (2005). Consuming visions: Mass culture and the Lourdes Shrine. Ithaca, NY: Cornell University Press.
Johnstone, S. (Ed.). (2008). The everyday. Cambridge, MA/ London: MIT Press and Whitechapel Gallery.

Lacombe, P. (2001). The Breton body in culture and religion. Culture, Sport, Society, 4(3), 27-48.

Le Braz, A. (1894). Au Pays des Pardons, Rennes, and Paris: Cailliere and Lemerre (Trans. by F. M. Gostling as The Land of Pardons, 1906). London: Clowes.

Massey, D. (1994). Space, place, and gender. Minneapolis, MN: University of Minnesota Press.

McDowell, L. (1999). Gender, identity and place: Understanding feminist geographies. Minneapolis, MN: University of Minnesota Press.

Michelet, J. (1861). La Mer. Paris: Hachette.

Nordau, M. (1907). On art and artists. Philadelphia, PA: Jacobs.

Orton, F., \& Pollock, G. (1980). Les Données Bretonnantes: La prairie de représentation. Art History, 3(3) 314-344.

Péron, F. (2004). The contemporary lure of the island. Tijdschrift voor Economische en Sociale Geografie, 95(3), 326-339.

Picard, D., \& Robinson, M. (2006). Festivals, tourism, and social change: Remaking worlds. Clevedon, UK: Channel View Publications.

Puget, C. (2006). Peintres de la Bretagne et quête spirituelle. Pont-Aven: Musée de Pont-Aven.

Salomé, K. (2003). Les îles bretonnes: Une image en construction (1750-1914). Rennes: Presses Universitaires de France.

Simon, J. F. (1997). La cheminée dans la maison bretonne. In G. Milin \& P. Galliou (Eds.), Hauts lieux du sacré en Bretagne (pp. 257-270). Brest: Centre de Recherche Bretonne et Celtique.

Thomson, R. (2004). The troubled republic: Visual culture and social debate in France, 1889-1900. New Haven: Yale University Press.

Urry, J. (1990). The tourist gaze: Leisure and travel in contemporary societies. London/Newbury Park: Sage Publications.

Weber, M. (1947). Science as a vocation. In H. Gerth \& C. Wright Mills, (Eds.), From Max Weber: Articles in sociology. New York: Oxford University Press.

Young, P. (2007). Of pardons, loss, and longing: Tourism and cultural value in Brittany, 1900-1930. French Historical Studies, 30, 237-67.

Young, P. (2009). Fashioning heritage: Regional costume and tourism in Brittany, 1890-1937. Journal of Social History, 42, 631-659. 